\title{
Microorganisms and their residues under restored perennial grassland communities of varying diversity
}

Chao Liang ${ }^{1,2}$ * Jenny Kao-Kniffin ${ }^{3}$ Gregg R. Sanford ${ }^{2,4}$ Kyle Wickings $^{3}$ Teri C. Balser $^{2,5}$ Randall D. Jackson ${ }^{2,4}$

1. Key Laboratory of Forest Ecology and Management, Institute of Applied Ecology, Chinese Academy of Sciences, Shenyang 110016, China

2. DOE-Great Lakes Bioenergy Research Center, University of Wisconsin, Madison, WI 53706, United States

3. College of Agriculture and Life Sciences, Cornell University, Ithaca, NY 14853, United States

4. Department of Agronomy, University of Wisconsin, Madison, WI 53706, United States

5. Faculty of Science and Engineering, Curtin University, Perth, Western Australia 


\section{Abstract:}

Rising atmospheric $\mathrm{CO}_{2}$ concentration and global mean temperatures have stimulated interest in managing terrestrial systems to sequester more carbon and mitigate climate change. In a restored prairie experiment, we compared high diversity (HD, 25 species) with low diversity (LD, 6 species) prairies to investigate the effect of plant diversity on soil microbial communities and their residues with soil depth. We assayed lipid and amino sugar biomarkers for soil samples, taken after 9 years following the establishment of the prairie treatment, at 5 depth increment layers: 0 to $2 \mathrm{~cm}, 12$ to $15 \mathrm{~cm}, 25$ to $27 \mathrm{~cm}, 50$ to $52 \mathrm{~cm}$, and 98 to $100 \mathrm{~cm}$. We found that the microbial biomass and residues decreased considerably with depth in both diversity treatments. Ordination analysis of lipid profiles indicated soil microbial communities were consistently distinct between the deeper and the upper layers, regardless of treatment, and also differed between the LD and HD treatments. Plant diversity effects on soil microbial communities strongly correlated with arbuscular mycorrhizal fungi (AMF), as indicated by the lipid marker 16:105c. Soil microbial residues in deeper horizons were relatively more enriched in HD than LD treatments, suggesting that greater plant diversity might sustain higher soil carbon storage through relatively recalcitrant necromass inputs in the long term. Decreasing glucosamine/muramic acid (GluN/MurA) ratio in LD and increasing in HD with depth suggested that the new microbially-accumulated carbon was positively contributed by fungal-derived residues. Our results indicate that plant diversity drives soil microbial carbon sequestration through changes in AMF abundance in restored native tallgrass ecosystems. These findings have implications for understanding how the management of plant diversity can improve soil quality and sustainability in grasslands, and how efforts to conserve and restore diverse grasslands could mitigate greenhouse gas emissions.

Key words: Microbial residue; Microbial community; Plant diversity; Soil depth; Biomarker; Grassland ecosystems 


\section{Introduction}

The potential of terrestrial ecosystems to be managed as net carbon (C) sinks is critical to mitigating climate forcing in the coming decades. Terrestrial ecosystems have the potential to store $\mathrm{C}$ in plants (representing a short-term $\mathrm{C}$ storage pool) via photosynthesis and $\mathrm{C}$ fixation, whereby a portion of the plant residues are incorporated into soil organic $\mathrm{C}$ (representing a longer-term C storage pool) (Schimel, 1995; Balser, 2005; Liang et al., 2011). The pool of C in soil is double the size of the atmospheric C, and dominates the terrestrial C pool (Schimel, 1995; Balser, 2005). Minor differences in soil C retention and stock levels, driven by microbial catabolic activity, could release stored soil $\mathrm{C}$ and have significant impacts on atmospheric $\mathrm{CO}_{2}$ (Rustad et al., 2000). Ecosystems vary in their storage rates of soil organic $\mathrm{C}$, and perennial grasslands are being examined for long-term $\mathrm{C}$ sequestration (Post and Kwon, 2000; Sanford, 2014). Practices that alter soil C sequestration in these grasslands (such as land-use and land-cover management) may thus serve to limit atmospheric $\mathrm{CO}_{2}$ concentrations and mitigate global climate warming (Lal, 2003).

Ultimately, soil $\mathrm{C}$ cycling is the consequence of microbial growth and activity, and thus a detailed understanding of soil microorganisms and microbe-mediated soil processes will enhance our understanding of $\mathrm{C}$ dynamics in soils. For example, microbial residues (microbial cellular components from both living and senesced biomass) are now recognized as playing a far greater role in soil C sequestration than previously believed (Simpson et al., 2007; Benner, 2011; Liang and Balser, 2011; Liang et al., 2011). Microbial communities differentially affect microbial-derived C production and accumulation (Amelung, 2001; Li et al., 2015), and mediate other processes that are important to soil C cycling (Schimel and Schaeffer, 2012). Variation in plant traits found in more diverse grasslands likely affect the quantity and quality of plant litter inputs and root exudates, as well as soil aggregation, which together, have the potential to influence microbial community composition and function (Haichar et al., 2008). However, the influence of plant diversity on soil microbial communities is not well understood, with some studies reporting that increased plant diversity stimulates microbial communities (Stephan et al., 2000; Loranger-Merciris et al., 2006; Herzberger et al., 2014), while others have found no effect (Wardle et al., 2003; Kielak et al., 2008). In addition, few studies have investigated the effect of plant diversity on microbial residues as part of the soil 
$\mathrm{C}$ pool, and even fewer have studied these at depths below $30 \mathrm{~cm}$. Microbial residues in particular merit study - as they are likely to contribute disproportionately to stable soil C pool (Liang et al., 2011; Miltner et al., 2012). Therefore, more knowledge of soil microbial community composition and microbial residues, as affected by plant diversity, is of value.

Quantitative investigations of microorganisms in soil has long been a challenge. Historically, study of soil microorganisms relied on culture-dependent methods, with which information is limited given the very small fraction of organisms that are cultivable in laboratory conditions (Hill et al., 2000). More recent quantitative approaches to characterizing microorganisms include those based on direct extraction and determination of biomarkers such as membrane lipids or cell wall amino sugars (Vestal and White, 1989; Glaser et al., 2004). Because of its high extraction efficiency and rapid degradation following cell death, lipid concentration in soil is considered a measure of living microbial biomass (Zelles, 1999). Lipid profiles have also been widely used as a "fingerprint" of microbial community composition, with certain lipids used as unique markers for specific microbial groups (Vestal and White, 1989; Zelles, 1999; Frostegårda et al., 2011). In addition, microbial "residues" (cell wall components and their degrading products) can be assessed by assaying soil for amino sugars. Amino sugars associated with microbial cell walls accumulate over time and thus provide a time-integrated estimate of microbial community turnover (Guggenberger et al., 1999; Amelung, 2001; Liang et al., 2008). Total amino sugar amounts can be used to assess the microbial contribution to soil organic matter (SOM) (Guggenberger et al., 1999; Glaser et al., 2006). Because individual amino sugars in soils have different microbial origins (Parsons, 1981; Amelung, 2001; Joergensen and Emmerling, 2006), the ratio of glucosamine/muramic acid has been widely used to assess the relative contribution of fungi and bacteria to soil organic C (Amelung, 2001; Liang and Balser, 2008). The two methods, lipid and amino sugar analysis, reflect different portions of microbial components with very different turnover times. Lipids have rapid turnover following cell death and represent the extant community, while amino sugars are reflective of both extant and past soil microbial communities due to their indefinite persistence in soil.

While there is consensus that the increasing loss of biodiversity within terrestrial ecosystems is likely to reduce the stability of aboveground ecosystems (Tilman et al., 2001; 
Catovsky et al., 2002; Hooper et al., 2005), only a small number of studies have investigated the impact of plant diversity on belowground biota and soil functioning. The mechanisms underpinning processes such as soil $\mathrm{C}$ stabilization, especially in relation to above-ground plant diversity, are not well understood (Wardle et al., 2004; Kielak et al., 2008; Cardinale et al., 2012; Lange et al., 2014). Recent studies have shown that a loss of plant diversity could undermine the capacity of soil to act as a C sink (Fornara and Tilman, 2008; Steinbeiss et al., 2008; De Deyn et al., 2011; Lange et al., 2015). To model and manage the soil C pool, it is essential that we understand how it has been affected in response to changes in plant diversity and land use.

Here, we investigated microbial community (cell membrane lipids) and microbial residue (cell wall amino sugars) distributions in two experimental treatments - low diversity prairie (LD) and high diversity prairie (HD) - at different soil depths in restored grasslands of southern Wisconsin. The overall aims of the study were to: 1) examine if plant diversity is associated with distinct microbial communities and/or microbial residues, with depth;2) evaluate plant diversity effects on microbial community composition and microbial residue storage, down to $100-\mathrm{cm}$ depth; and 3) quantify the microbial cell wall residues within a 100-cm soil profile in prairie, with two levels of plant diversity.

\section{Materials and methods}

\subsection{Site description and sampling}

We conducted this work at the Wisconsin Integrated Cropping System Trial (WICST), located at the University of Wisconsin's Agricultural Research Station near Arlington, Wisconsin. Initiated in 1999, the WICST Prairie Establishment Experiment (43¹7’44.64’N, $\left.89^{\circ} 22^{\prime} 46.90^{\prime \prime} \mathrm{W}\right)$ focused on the restoration success of two native seed mixes containing different diversity levels (HD, $\mathrm{n}=25$ and $\mathrm{LD}, \mathrm{n}=6$ species; Table 1 ). The LD seed mixes contained 2 grasses, 2 legumes and 2 forbs. In addition to the 6 species of the LD treatment, the HD seed mixes included 19 additional species with 3 grasses, 4 legumes, 17 forbs and 1 woody shrub. Treatment plots - HD and LD - were established in a randomized complete block design with three replicates. Each replicate plot measured ca. 2,000 $\mathrm{m}^{2}$ (155 m long by $13.7 \mathrm{~m}$ wide). All LD and HD plots were burned in spring every 2 to 3 years. The soils of the 
site were classified as a Plano Silt Loam, fine-silty, mixed, superactive, mesic typic argiudolls (Soil Survey Staff, 1999). The mean annual temperature and precipitation were $6.8^{\circ} \mathrm{C}$ and 869 mm, respectively (1981-2010, National Climate Data Center) (NWS, 2013; Sanford et al., 2016).

We sampled one 100-cm deep soil core from each experiment unit in November 2008 using a tractor-mounted Giddings hydraulic soil sampler fitted with a $5.4 \mathrm{~cm}$ diameter soil core. Stratified soil samples were collected from 5 intervals taken from the soil horizon at 0 to $2 \mathrm{~cm}, 12$ to $15 \mathrm{~cm}, 25$ to $27 \mathrm{~cm}, 50$ to $52 \mathrm{~cm}$, and 98 to $100 \mathrm{~cm}$ (Fig. S1). These intervals were located at the transition points of soil horizons determined by transitions in soil physical and chemical parameters. Their location insures that they characterize the soil microbial properties to depth while not limiting collection of soils for soil physiochemical analysis. Soil cores inside of the plastic tubes were stored at $4{ }^{\circ} \mathrm{C}$ until further processing during which each depth interval was frozen, freeze-dried, homogenized and stored in $-20{ }^{\circ} \mathrm{C}$.

\subsection{Soil assays}

\subsubsection{Microbial lipids}

We used a modified procedure of phospholipid fatty acid (PLFA) and fatty acid methyl ester (FAME) analysis to assay microbial community composition (Kao-Kniffin and Balser, 2007; Liang et al., 2015). The procedure was based on the extraction of signature lipid biomarkers from the cell membrane of microorganisms. Lipids were extracted, purified and identified using steps from a modified lipid extraction technique first described by Bligh and Dyer (1959) for lipid extraction, combined with FAME as described by Microbial ID, Inc. (Hayward, CA). Briefly, approximately 3 g lyophilized soil was extracted with phosphate buffer-chloroform-methanol (2.7 ml-3.0 ml-6.0 ml). We analyzed extracts with a Hewlett-Packard Agilent 6890A GC (Agilent Tech. Co., Santa Clara, CA) equipped with a $25-\mathrm{m} \times 0.2-\mathrm{mm} \times 0.33-\mu \mathrm{m}$ Agilent Ultra-2 (5\% phenyl)-methylpolysiloxane capillary column (Hewlett Packard, Palo Alto, CA) and flame ionization detector (FID). MIDI's EUKARY method database was used to identify fatty acids. We added 19:0 (nonadecanoic methyl ester) and 9:0 (nonanoic methyl ester) as internal standards and used them to convert fatty acid peak areas to $\mathrm{nmol} / \mathrm{g}$ soil (absolute abundance) and mol\% (proportional abundance). We quantified the abundance of different microbial groups using the abundance of signature lipids (Vestal 
and White, 1989; Frostegårda et al., 2011). The lipids we analyzed in our study include both phospho- and neutral fatty acid fractions. Microbial biomass was estimated as the sum of all identifiable lipids (carbon number < 20) (Kao-Kniffin and Balser, 2007; Liang et al., 2015). We used the sum of i14:0, a15:0, i15:0, i16:0, a17:0 and i17:0 to indicate Gram-positive bacteria $(\mathrm{Gm}+)$, and the sum of $16: 12 \mathrm{OH}, 16: 1 \omega 7 \mathrm{c}, 16: 1 \omega 9 \mathrm{c}, \mathrm{cyc} 17: 0,17: 1 \omega 8 \mathrm{c}, 18: 1 \omega 7 \mathrm{c}$, cyc19:0 to indicate Gram-negative bacteria $\left(\mathrm{Gm}^{-}\right)$(Ratledge and Wilkinson, 1988; Zogg et al., 1997). The sum of 10Me16:0, 10Me17:0 and 10Me18:0 indicates actinomycetes (Lechevalier and Moss, 1977). Eukaryotic microbial groups identified in this study included arbuscular

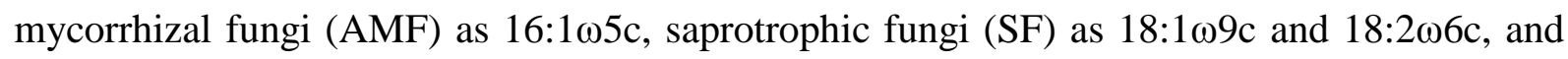



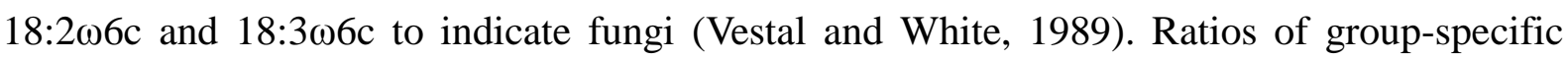
lipids were taken to reflect the relative biomass of their respective groups (Bardgett et al., 1996; Liang et al., 2008).

\subsubsection{Microbial amino sugars}

We determined four amino sugars by gas chromatography $(\mathrm{GC})$ after their conversion to aldonitrile acetates (Guerrant and Moss, 1984; Zhang and Amelung, 1996), as modified by Liang et al. (2012). The procedure was based on the extraction of signature amino sugar biomarkers from the cell wall of microorganisms. Briefly, approximately $1 \mathrm{~g}$ lyophilized soil samples were hydrolyzed with $6 \mathrm{M} \mathrm{HCl}$ at $105{ }^{\circ} \mathrm{C}$ for $8 \mathrm{~h}$ to release the amino sugar monomers. After purification and derivatization, we analyzed extracts with an Agilent 6890 GC (Agilent Technologies, Wilmington. DE, USA) equipped with a J\&W Scientific Ultra-2 column $(25-\mathrm{m} \times 0.2-\mathrm{mm} \times 0.33-\mu \mathrm{m})$ and flame ionization detector. The individual amino sugar derivatives were identified by comparing their retention time with those of authentic standards. Quantification from peak areas to mass per mass of soil $(\mu \mathrm{g} / \mathrm{g})$ was gained relative to the internal standard myo-inositol, which was added to the samples prior to purification. We also used the recovery standard N-methylglucamine, added before derivatization to assess the efficiency of the derivatization step. Muramic acid (MurA) is found in the bacterial cell wall peptidoglycan and is not produced by eukaryotic cells (Amelung, 2001; Joergensen and Emmerling, 2006). Equal amounts of MurA and glucosamine (GluN) are found in bacterial peptidoglycan, but in soils GluN predominantly originates from fungal chitin rather than 
bacterial peptidoglycan (Parsons, 1981; Amelung, 2001). The origin of galactosamine (GalN) or mannosamine (ManN) is currently debated (Glaser et al., 2004; Engelking et al., 2007).

\subsubsection{Soil physiochemical analysis}

Soil texture was determined on three 50-g samples from each treatment using a standard hydrometer method (Bouyoucos, 1962). Additional samples from each treatment and depth (100 g) were sent to the University of Wisconsin Soil and Plant Analysis Lab for determination of $\mathrm{pH}\left(1: 1\right.$, soil to water), organic matter (weight loss-on-ignition, $360{ }^{\circ} \mathrm{C}$ ), available $\mathrm{P}$ and $\mathrm{K}$ (Bray P1 extract), exchangeable $\mathrm{Ca}$ and $\mathrm{Mg}\left(1 \mathrm{~N} \mathrm{NH} \mathrm{N}_{4} \mathrm{OAc}, \mathrm{pH} 7.0\right)$, and calculated cation exchange capacity (CEC). To determine total C, finely ground subsamples of soil from each treatment were weighed $(8-10 \mathrm{mg})$, packed into a 5 x 9-mm tin capsule, and analyzed on a FlashEA 1112 CN Automatic Elemental Analyzer (Thermo Finnigan, Milan, Italy).

\subsection{Data analysis}

We used a generalized linear mixed model (GLMM) to test the effects of plant diversity and depth on soil properties, where we treated the variables as categorical. The GLMM formula is: soil variable $\sim$ plant diversity + depth + plant diversity $*$ depth, including soil cores as a random factor using "nlme" package of R (Pinheiro et al., 2009). We used principal components analysis (PCA) to depict difference in soil attribute-induced pattern, and to assess microbial community shifts based on the relative proportion of identified microbial lipids. Lipids with $<0.5 \%$ relative abundance were excluded, and the remaining lipids (i.e., C14-C20) were arcsin-transformed to ensure normality before ordination. To relate factors to soil microbial residue amino sugars, we conducted redundancy analysis (RDA) with amino sugars as a dependent variable and with fungal lipids, bacterial lipids, depth, and plant diversity as explanatory variables using the "vegan" package of R (Oksanen, 2010). All amino sugar data were standardized from an absolute concentration distribution characterized by a mean and standard deviation before the RDA. The proportions of explained variation in RDA were calculated using adjusted R-squared values as described by Peres-Neto et al. (2006).

To describe the dynamics of amino sugars and lipids with depth, we used a lograrithmic model: $\mathrm{y}=\mathrm{a}-\mathrm{b} * \operatorname{Ln}(\mathrm{x})$, where $\mathrm{y}$ represented the lipid or amino sugar concentration and $\mathrm{x}$ represented soil depth. Coefficients of correlation $\left(\mathrm{R}^{2}\right)$ indicated goodness-of-fit. Because the 
amino sugar contents were obtained from small increments of soils at soil horizon transitions, we built and compared two models to estimate the microbial residue pool size across the entire soil core profile (i.e., 0 to $100 \mathrm{~cm}$ ). The two solutions to quantify amino sugar pool size (S) throughout the soil profile were based on five amino sugar concentrations (p1, p2, p3, p4, p5), four bulk densities (bd1, bd2, bd3, bd4), and a regression function.

Solution 1: $\mathrm{S}=\left(\frac{\mathrm{p}_{1}+\mathrm{p}_{2}}{2}\right) * b d_{1} * 10+\left(\frac{\mathrm{p}_{2}+\mathrm{p}_{3}}{2}\right) * \mathrm{bd}_{2} * 15+\left(\frac{\mathrm{p}_{3}+\mathrm{p}_{4}}{2}\right) * \mathrm{bd}_{3} * 25+\left(\frac{\mathrm{p}_{4}+\mathrm{p}_{5}}{2}\right) * b d_{4} * 50$

Solution 2: $\quad y=a-b \operatorname{Ln}(x) \Rightarrow x=e^{\frac{a-y}{b}}$

$$
\mathrm{S}=\mathrm{bd} d_{1} * \int_{0}^{10} \mathrm{e}^{\frac{\mathrm{a}-\mathrm{y}}{\mathrm{b}}} \mathrm{dy}+\mathrm{bd} d_{2} * \int_{10}^{25} \mathrm{e}^{\frac{\mathrm{a}-\mathrm{y}}{\mathrm{b}}} \mathrm{dy}+\mathrm{bd}_{3} * \int_{25}^{50} \mathrm{e}^{\frac{\mathrm{a}-\mathrm{y}}{\mathrm{b}}} \mathrm{dy}+\mathrm{bd} d_{4} * \int_{50}^{100} \mathrm{e}^{\frac{\mathrm{a}-\mathrm{y}}{\mathrm{b}}} \mathrm{dy}
$$

We found differences between these two solutions to be insignificant $(<0.1 \%)$ here, so we reported amino sugar pool size according to Solution 2 by integrating the regression function with depth.

\section{Results}

\subsection{Soil physicochemical properties varied strongly with depth}

The measured physicochemical indices showed a distinct vertical pattern, while the effects of plant diversity were not apparent. The GLMM analysis identified the significant effects of soil depth on TC, TN, SOM, P, K, Mg, soil texture and bulk density, but not on C/N ratio, $\mathrm{pH}$ value, $\mathrm{Ca}$ and CEC (Table 2). In contrast, plant diversity, alone or in interaction with depth, was not significantly related to any measured physicochemical properties $(\mathrm{p}>0.05$, Table 2). In terms of each depth layer, differences in all measured physicochemical indices were not significant $(\mathrm{p}>0.05)$ between the two plant diversity treatments. These trends were further supported by PCA (Fig. 1A) which showed distinct grouping by depth, rather than by diversity treatment, i.e. plant diversity effects are not evidently affected by differences in the studied physicochemical properties (especially little related to soil texture).

\subsection{Lipid biomass and pattern of plant diversity treatments with depth}

A total of 47 different fatty acids were identified. Of these, 33 were consistently present in the samples and were used for calculating lipid biomass and ordination analysis. The 33 
fatty acids, known to be of microbial origin, ranged in C-chain length from C14 to C20 including saturated, unsaturated, methyl-branched, hydroxylated, and cyclopropane fatty acids. In all plant diversity treatments the absolute abundance (ug/g soil) of AMF, SF, Gm+, Gmand total microbial lipid biomass dramatically decreased with increasing soil depth (Fig. 2).

Ordination analysis of the lipid data suggested a differentiation in microbial communities among plant diversity and soil depth layers (Fig. 1B). In the PCA plot, the first principal component axis (PC1) explained $30.2 \%$ of the variance in the data while the second principal component axis (PC2) explained 20.3\%. Overall, the variance in lipid signatures from replicate samples was higher in deeper layers than in surface layers. The significant difference of lipid signatures between the LD and the HD treatments, and along the depth gradient in each diversity treatment were distinct (Fig. 1B). Specifically, the plant diversity effect was showed to strongly correlated with the AMF lipid marker 16:1 $15 \mathrm{c}$, while the depth effect was controlled largely by signature lipids for $\mathrm{Gm}+$ and $\mathrm{Gm}$ - bacteria, where those lipids showed positive correlation along a depth gradient (Fig. 1B).

\subsection{Amino sugar yield and pattern of plant diversity treatments with depth}

Among the four individual amino sugars we assayed, we chose to focus on MurA, GluN and GalN because of their relatively clear origin or enriched abundance. Amino sugar amounts in this study were reported based on sample weight (ug/g soil) to indicate the absolute accumulation of amino sugars in our samples. Total amino sugar amounts declined substantially with depth in both LD and HD treatments, accompanying a significant decrease in total soil C amount (Fig. 3). Specifically, surface soils $(0-2 \mathrm{~cm})$ in the LD significantly (p < 0.05) accumulated more amino sugars than HD, while amino sugars were significantly $(\mathrm{p}<$ 0.05) more enriched in deep soils $(98-100 \mathrm{~cm}$ ) of HD compared to LD (Fig. 3). The relative fungal to bacterial contribution to microbial residues, indicated by the GluN/MurA ratio, decreased with depth in LD, but increased in HD (Fig. 4). Between the two plant diversity treatments the GluN/MurA ratio in the surface soil of the LD was higher, while the ratio of the deepest soil in HD was higher.

The RDA (Model formula: Amino sugars Lipids + Depth + Diversity) revealed the relative impacts of soil microbial groups, soil depth, and plant diversity factors on the soil microbial residues (Fig. 5). Here, we showed the first two components of RDA axes, where 
axis 1 and axis 2 explained $77.6 \%$ and $7.6 \%$ of total variation, respectively. We found that the GluN, GalN and MurA generally had positive correlations with main lipid guilds (AMF, $\mathrm{SF}, \mathrm{Gm}+$ and Gm- bacteria). In particular, we found that the amino sugar amounts were significantly influenced by Gm+ bacteria $(\mathrm{p}<0.01)$, Gm- bacteria $(\mathrm{p}<0.05)$, and soil depth $(\mathrm{p}<0.001)$ (Fig. 5).

\subsection{Pool size of microbial amino sugars within $100-\mathrm{cm}$ soil profile}

When estimating the pool size of amino sugars and their relative proportion in SOM within the $100-\mathrm{cm}$ soil profile, we found the LD plots had the lower amino sugar amounts particularly at depth. Amino sugar proportion in SOM for the LD plots appears to be lower compared to more diverse prairie plots (Fig. 6). Relative to LD, the amino sugar pool within the $100-\mathrm{cm}$ soil profile increased $17.3 \%$ in HD, while the amino sugar proportion in SOM increased $21.8 \%$ in HD. In terms of the relative contribution of amino sugar amounts to the total $\mathrm{C}$ and $\mathrm{N}$ pools within $100-\mathrm{cm}$ profile, the contribution increased $5.7 \%$ and $10 \%$ in $\mathrm{HD}$, respectively.

\section{Discussion}

Our ordination results further confirmed that microbial communities and residues significantly differ with soil depth (Fritze et al., 2000; Fierer et al., 2003; Moritz et al., 2009; Sradnick et al., 2014). In addition, the habitat niche (depth in soils) has a much stronger effect than plant diversity in controlling microbial community composition and residues, underscoring the importance of belowground habitat versus aboveground plant diversity.

The importance of vertical spatial heterogeneity is expected as soil depth directly impacts resource availability and habitat quality of soil microorganisms in predictable ways (Fierer et al., 2003). The absolute abundances of total microbial biomass and main microbial groups in our study decreased with increasing depth, with most individual signature lipids being negatively correlated to soil depth, as also observed with similar patterns for other soil profiles (Fritze et al., 2000; Fierer et al., 2003). Plant diversity, in contrast, influences microbial communities in less predictable ways, as the quantity and quality of substrate inputs, nutrient availability, and habitat differentiation differs across plant species, genotypes, and assemblages (Stephan et al., 2000; Tilman et al., 2001). Here, the high association of plant 
diversity with abundance of the AMF lipid marker 16:1 $105 \mathrm{c}$ suggests that the high diversity prairie supports AMF dominance in those soils. This supports the findings by Thorms et al. (2010) who proposed specific direct interactions between plant diversity and AMF, which was indicated by a strong correlation to the same marker. Recent work has shown that the establishment of diverse prairie in these soils can result in a rapid ( 2 years $)$ soil microbial community shift toward greater AMF (Herzberger et al., 2014). Our findings thus reinforce the relationship between plant diversity and AMF abundance. If nothing else, given the sensitivity of fungi to external disruption, and the importance of AMF to ecosystem functioning (Treseder et al., 2007), this work indicates the importance of preserving plant diversity in order to support the fungal community.

Unlike lipid-based fingerprinting methods, microbial amino sugar biomarkers act to integrate changes in microbial communities over time (Glaser et al., 2004; Liang et al., 2015). We expected amino sugars to be significantly related to both soil depth and in some way to our characterization of soil microbial community lipid composition. The lack of significant explanatory detection of a direct correlation to amino sugars by plant diversity and/or fungal groups (Fig. 5) is likely due to the complexity of underlying mechanisms at these sites. The effect of depth on soil amino sugars in the plant diversity treatments differed, with significantly higher amino sugar levels in the top layer of LD compared to HD (Fig. 3). Specifically, the fungal-derived GluN amount in the top layer of LD (955.9 ug/g-soil) is higher than HD (652.1 ug/g-soil), while the bacterial-derived MurA amount in LD (36.0 $\mathrm{ug} / \mathrm{g}$-soil) is lower than HD (50.1 ug/g-soil). One or both of two explanations for these results are plausible. First, increased competition for nutrients (among plants and microbes) in the HD could restrict fungal biomass production and/or turnover resulting in lower amino sugar production and accumulation over time, with concomitant lower influx into the amino sugars pool. Alternatively, competition for nutrients among plants in the HD treatment might lead to enhanced rhizodeposition resulting in bacterial priming and degradation of microbial amino sugars for $\mathrm{N}$ access to maintain plant growth (i.e. production of amino sugars could be the same as in LD, but amino sugar turnover is higher - the outflow from the amino sugars pool is higher). The pattern at depth was reversed, with relatively higher amino sugar levels in the HD treatment. Specifically, the fungal-derived GluN amount and bacterial-derived MurA 
amount in the bottom layer of HD are both higher than LD (134.9 ug/g-soil > 50.9 ug/g-soil for GluN and $5.1 \mathrm{ug} / \mathrm{g}$-soil > $3.9 \mathrm{ug} / \mathrm{g}$-soil for MurA). This demonstrates placement of fungal and bacterial residues in a more diverse site - due to the wider range of plant species and rooting depth, there is likely to be greater production of microbial biomass and accumulation of microbial residues at depth in the HD (Moritz et al., 2009). It may be an effect that is small (i.e. not detected here in the surface soil with its more rapid cycling of $\mathrm{C}$ ), but that given enough time becomes noticeable.

The lack of correlations (Fig. 5) between AMF and SF to soil amino sugars could be explained by preferred fungal utilization of accumulated microbial residues in soils. Fungi are general more able to decompose relatively stable organic matter, which includes accumulated amino sugars (Ley and Schmidt, 2002; Liang and Balser, 2008). Ideally, greater microbial biomass will produce more cells, resulting in more microbial residues. However, preferential utilization of amino sugars would alter the balance between amino sugar production (microbial biomass) and degradation (Liang et al., 2007) and consequently alter the linear relationship between microbial biomass and accumulated amino sugars.

Ultimately, microbial community properties (biomass and composition) drive soil microbial residue dynamics through microbial cell production and turnover. Changes in the composition of the soil microbial community via management of plant diversity can therefore influence soil $\mathrm{C}$ by influencing microbial residues. However, we only found strong explanatory power of bacterial community markers with respect to the microbial residue amino sugars. Our RDA analysis suggested that new $\mathrm{C}$ in soils (microbially-sequestered residues) may accumulate via increased microbial community abundance over time, with $\mathrm{Gm}+$ and Gm- bacteria playing a significant role. Moreover, we found that the relative fungal to bacterial contribution (GluN/MurA ratio) decreased with depth in LD, but increased with depth in $\mathrm{HD}$, suggesting that new accumulated $\mathrm{C}$ was positively related to fungal-derived more than bacterial-derived residues. Further, increased plant diversity may promote the accrual of total soil microbial residues, and in particular, with higher GluN/MurA ratios in HD deeper soil layers and lower ratios in LD surface soils, which points to the predominant role of fungi in total microbial residue storage in soils.

Ecosystem management involving the manipulation of plant species richness may 
influence soil chemical, physical and biological properties. It is well known that microbial communities and their activities are sensitive to shifts in soil characteristics in response to land management, and there is growing evidence that soil microbiological parameters may serve as early and sensitive indicators for soil degradation and restoration (Powlson et al., 1987; Anderson, 2003; McKinley et al., 2005). Our data support the concept that microbial cell biomarkers, lipids and amino sugars, serve as promising diagnostic tools in assessing the role of plant diversity in maintaining desirable soil quality traits; however, our findings indicate that changes in microbial traits were not driven by differences in soil physicochemical properties. Here, the small differences in soil properties between two plant diversity treatments following 9-years of management suggest that plant diversity-driven differences in soil microbial communities and residues may not have been significantly mediated via soil properties in a direct way compared to others. However, the possibility that microbial communities and residues were influenced by other soil characteristics not measured in this study, such as soil moisture, dissolved organic $\mathrm{C}$ and inorganic $\mathrm{N}$ concentrations, cannot be ruled out.

By estimating the microbial residue contribution to SOM within 100-cm soil profiles as compared to the often-studied 0-30 cm depths, we suggest that HD might sustain higher soil C sequestration by relatively recalcitrant necromass inputs over the long-term. Specifically, we showed that the management of plant diversity over 9 years can enhance microbial amino sugar accumulation by $10.3 \mathrm{mg} / \mathrm{cm}^{2}$ within $100-\mathrm{cm}$ depth. The analysis of lipid and amino sugar biomarkers in a long-term grassland biodiversity experiment established in the North Central U.S. served to provide important insights into soil health and C sequestration grassland restoration with greater plant diversity can increase ecosystem service through the enhancement of stable soil C pool by microbial residue inputs. Further studies with a focus on functional guilds of plants as well as the evenness (relative abundance) of plant diversity would gain additional insights on the selective pressures of plant species that shape microbial communities and microbial-derived residues in natural and managed terrestrial ecosystems.

\section{Acknowledgements}

We would like to thank Dr. Josh Posner, in great memory, for his foresight in setting up the 
WICST trials, and Janet Hedtcke for field and logistical support. Dr. Harry Read was invaluable for his help with laboratory analyses, and Dr. Jinsong Zhao with statistical expertise. This work was supported by the China funds from the National Key Research and Development Program (2016YFA0600802), the Strategic Priority Research Program of the Chinese Academy of Sciences (No. XDB15010303), the Natural Science Foundation of China (41471218), and by the U.S. funds from the DOE-Great Lakes Bioenergy Research Center (DOE BER Office of Science DE-FC02-07ER64494). 


\section{$\underline{\text { Figure Captions }}$}

Figure 1. Principal component analysis $(\mathrm{PCA})$ of soil attributes $(\mathrm{n}=24)$ and microbial lipid fingerprints $(\mathrm{n}=30)$ from two diversity-varied grassland treatments. (A) PCA score plot of 13 edaphic factors and (B) PCA score plot of 33 microbial lipids. Error bars represent \pm standard errors of the means. The sampling sites are scaled by the solid line axes (bottom and left), and the variables are scaled by the dotted line axes (top and right).

Note: Only the first two axes are displayed. Red square and green circle represent low diversity and high diversity prairie sites, respectively. The increasing gradient of the symbols' size indicates the samples from surface to bottom layer.

Figure 2. The soil total and group microbial biomass by lipid yield through 100-cm soil depth from two diversity-varied grassland treatments. The biomass is calculated based on absolute amount $(\mu \mathrm{g} / \mathrm{g})$ of guild lipids. Red square and green circle represent low diversity and high diversity prairie sites, respectively. AMF, SF, $\mathrm{Gm}+$ and $\mathrm{Gm}-$ represent arbuscular mycorrhizal fungi, saprotrophic fungi, Gram-positive bacteria and Gram-negative bacteria, respectively. Error bars represent \pm standard errors of the means.

Figure 3. Depth distributions of the total carbon and amino sugar amount from two grassland diversity treatments. Error bars represent the standard errors of the means.

Figure 4. GluN/MurA ratios across soil depths from two grassland diversity treatments. Error bars represent the standard errors of the means.

Figure 5. Redundancy analysis (RDA) biplot based on 3 microbial amino sugars, 33 microbial lipids and 2 categorical variables (soil depth and plant diversity). The sampling sites were scaled by the solid line axes (bottom and left), and the amino sugars and explanatory lipids and two categorical variables are scaled by the dotted line axes (top and right). Significant explanatory variables are indicated by asterisks. Permutation test is based on 999 iterations. Significance is indicated as: $* \mathrm{p}<0.05$, ** $\mathrm{p}<0.01, * * * \mathrm{p}<0.001$. The proportion 
of explained variation was calculated by using adjusted R-squared values as described by Peres-Neto et al. (2006).

Note: Red square and green circle represent low diversity and high diversity prairie sites, respectively. The increasing gradient of the symbols' size indicates the samples from surface to bottom layer.

Figure 6. Total amino sugar amount and its proportional contribution to SOM, TC and TN pool across soil depths from two grassland diversity sites. LD and HD represent low diversity prairie and high diversity prairie site, respectively. 


\section{References}

1. Amelung, W., 2001. Methods using amino sugars as markers for microbial residues in soil, In: Lal, R., J.M. Kimble, R.F. Follett, B.A. Stewart (Ed.), Assessment Methods for Soil Carbon. CRC/Lewis Publishers, Boca Raton, FL, pp. pp. 233-270.

2. Anderson, T.-H., 2003. Microbial eco-physiological indicators to asses soil quality. Agriculture, Ecosystems \& Environment 98, 285-293.

3. Balser, T.C., 2005. Humification, In: Hillel, D. (Ed.), Encyclopedia of Soils in the Environment. Elsevier, Oxford, UK., pp. 195-207.

4. Bardgett, R.D., Hobbs, P.J., Frostegård, A., 1996. Changes in soil fungal/bacterial biomass ratios following reductions in the intensity of management of an upland grassland. Biology and Fertility of Soils 22, 261-264.

5. Benner, R., 2011. Biosequestration of carbon by heterotrophic microorganisms. Nat Rev Micro 9, 75-75.

6. Bligh, E.G., Dyer, W.J., 1959. A rapid method of total lipid extraction and purification. Canadian Journal of Physiology and Pharmacology 37, 911-917.

7. Bouyoucos, G.J., 1962. Hydrometer method improved for making particle size analyses of soils. Agronomy Journal 54, 464-465.

8. Cardinale, B.J., Duffy, J.E., Gonzalez, A., Hooper, D.U., Perrings, C., Venail, P., Narwani, A., Mace, G.M., Tilman, D., Wardle, D.A., Kinzig, A.P., Daily, G.C., Loreau, M., Grace, J.B., Larigauderie, A., Srivastava, D.S., Naeem, S., 2012. Biodiversity loss and its impact on humanity. Nature 486, 59-67.

9. Catovsky, S., Bradford, M.A., Hector, A., 2002. Biodiversity and ecosystem productivity: implications for carbon storage. Oikos 97, 443-448.

10. De Deyn, G.B., Shiel, R.S., Ostle, N.J., McNamara, N.P., Oakley, S., Young, I., Freeman, C., Fenner, N., Quirk, H., Bardgett, R.D., 2011. Additional carbon sequestration benefits of grassland diversity restoration. Journal of Applied Ecology 48, 600-608.

11. Engelking, B., Flessa, H., Joergensen, R.G., 2007. Shifts in amino sugar and ergosterol contents after addition of sucrose and cellulose to soil. Soil Biology and Biochemistry 39, 2111-2118.

12. Fierer, N., Schimel, J.P., Holden, P.A., 2003. Variations in microbial community composition through two soil depth profiles. Soil Biology and Biochemistry 35, 167-176.

13. Fornara, D.A., Tilman, D., 2008. Plant functional composition influences rates of soil carbon and nitrogen accumulation. Journal of Ecology 96, 314-322.

14. Fritze, H., Pietikäinen, J., Pennanen, T., 2000. Distribution of microbial biomass and phospholipid fatty acids in Podzol profiles under coniferous forest. European Journal of Soil Science 51, 565-573.

15. Frostegårda, Å., Tunlid, A., Bååth, E., 2011. Use and misuse of PLFA measurements in soils. Soil Biology and Biochemistry 43, 1621-1625.

16. Glaser, B., Millar, N., Blum, H., 2006. Sequestration and turnover of bacterial- and fungal-derived carbon in a temperate grassland soil under long-term elevated atmospheric $\mathrm{CO}_{2}$. Global Change Biology 12, 1521-1531.

17. Glaser, B., Turrion, M.B., Alef, K., 2004. Amino sugars and muramic acid - biomarkers for soil microbial community structure analysis. Soil Biology \& Biochemistry 36, 399-407.

18. Guerrant, G.O., Moss, C.W., 1984. Determination of monosaccharides as aldononitrile, O-methyloxime, alditol, and cyclitol acetate derivatives by gas-chromatography. Analytical Chemistry 56, 633-638.

19. Guggenberger, G., Frey, S.D., Six, J., Paustian, K., Elliott, E.T., 1999. Bacterial and fungal cell-wall residues in conventional and no-tillage agroecosystems. Soil Science Society of America Journal 63, 1188-1198.

20. Haichar, F.Z., Marol, C., Berge, O., Rangel-Castro, J.I., Prosser, J.I., Balesdent, J., Heulin, T., Achouak, W., 2008. Plant host habitat and root exudates shape soil bacterial community structure. ISME J 2, 1221-1230. 
21. Herzberger, A.J., Duncan, D.S., Jackson, R.D., 2014. Bouncing back: Plant-associated soil microbes respond rapidly to prairie establishment. PLoS ONE 9, e115775.

22. Hill, G.T., Mitkowski, N.A., Aldrich-Wolfe, L., Emele, L.R., Jurkonie, D.D., Ficke, A., Maldonado-Ramirez, S., Lynch, S.T., Nelson, E.B., 2000. Methods for assessing the composition and diversity of soil microbial communities. Applied Soil Ecology 15, 25-36.

23. Hooper, D.U., Chapin, F.S., Ewel, J.J., Hector, A., Inchausti, P., Lavorel, S., Lawton, J.H., Lodge, D.M., Loreau, M., Naeem, S., Schmid, B., Setälä, H., Symstad, A.J., Vandermeer, J., Wardle, D.A., 2005. Effects of biodiversity on ecosystem functioning: a consensus of current knowledge. Ecological Monographs 75, 3-35.

24. Joergensen, R.G., Emmerling, C., 2006. Methods for evaluating human impact on soil microorganisms based on their activity, biomass, and diversity in agricultural soils. Journal of Plant Nutrition and Soil Science 169, 295-309.

25. Kao-Kniffin, J., Balser, T.C., 2007. Elevated CO2 differentially alters belowground plant and soil microbial community structure in reed canary grass-invaded experimental wetlands. Soil Biology and Biochemistry 39, 517-525.

26. Kielak, A., Pijl, A.S., Van Veen, J.A., Kowalchuk, G.A., 2008. Differences in vegetation composition and plant species identity lead to only minor changes in soil-borne microbial communities in a former arable field. FEMS Microbiology Ecology 63, 372-382.

27. Lal, R., 2003. Global potential of soil carbon sequestration to mitigate the greenhouse effect. Critical Reviews in Plant Sciences 22, 151-184.

28. Lange, M., Eisenhauer, N., Sierra, C.A., Bessler, H., Engels, C., Griffiths, R.I., Mellado-Vazquez, P.G., Malik, A.A., Roy, J., Scheu, S., Steinbeiss, S., Thomson, B.C., Trumbore, S.E., Gleixner, G., 2015. Plant diversity increases soil microbial activity and soil carbon storage. Nat Commun 6, 6707.

29. Lange, M., Habekost, M., Eisenhauer, N., Roscher, C., Bessler, H., Engels, C., Oelmann, Y., Scheu, S., Wilcke, W., Schulze, E.-D., Gleixner, G., 2014. Biotic and abiotic properties mediating plant diversity effects on soil microbial communities in an experimental grassland. PLoS ONE 9, e96182.

30. Lechevalier, M.P., Moss, C.W., 1977. Lipids in bacterial taxonomy - A taxonomist's view. CRC Critical Reviews in Microbiology 5, 109-210.

31. Ley, R.E., Schmidt, S.K., 2002. Fungal and bacterial responses to phenolic compounds and amino acids in high altitude barren soils. Soil Biology and Biochemistry 34, 989-995.

32. Li, N., Xu, Y., Han, X., He, H., Zhang, X., Zhang, B., 2015. Fungi contribute more than bacteria to soil organic matter through necromass accumulation under different agricultural practices during the early pedogenesis of a Mollisol. European Journal of Soil Biology 67, 51-58.

33. Liang, C., Balser, T.C., 2008. Preferential sequestration of microbial carbon in subsoils of a glacial-landscape toposequence, Dane County, WI, USA. Geoderma 148, 113-119.

34. Liang, C., Balser, T.C., 2011. Microbial production of recalcitrant organic matter in global soils: implications for productivity and climate policy. Nat Rev Micro 9, 75.

35. Liang, C., Cheng, G., Wixon, D., Balser, T., 2011. An Absorbing Markov Chain approach to understanding the microbial role in soil carbon stabilization. Biogeochemistry 106, 303-309.

36. Liang, C., Fujinuma, R., Balser, T.C., 2008. Comparing PLFA and amino sugars for microbial analysis in an Upper Michigan old growth forest. Soil Biology and Biochemistry 40, 2063-2065.

37. Liang, C., Gutknecht, J., Balser, T., 2015. Microbial lipid and amino sugar responses to long-term simulated global environmental changes in a California annual grassland. Frontiers in Microbiology 6, 385.

38. Liang, C., Read, H.W., Balser, T.C., 2012. GC-based detection of aldonitrile acetate derivatized glucosamine and muramic acid for microbial residue determination in soil samples: analytical protocol and derivative 
validation. Journal of Visualization Experiment 63, e3767.

39. Liang, C., Zhang, X., Rubert, K.F., Balser, T.C., 2007. Effect of plant materials on microbial transformation of amino sugars in three soil microcosms. Biology and Fertility of Soils 43, 631-639.

40. Loranger-Merciris, G., Barthes, L., Gastine, A., Leadley, P., 2006. Rapid effects of plant species diversity and identity on soil microbial communities in experimental grassland ecosystems. Soil Biology and Biochemistry 38, 2336-2343.

41. McKinley, V.L., Peacock, A.D., White, D.C., 2005. Microbial community PLFA and PHB responses to ecosystem restoration in tallgrass prairie soils. Soil Biology and Biochemistry 37, 1946-1958.

42. Miltner, A., Bombach, P., Schmidt-Brücken, B., Kästner, M., 2012. SOM genesis: Microbial biomass as a significant source. Biogeochemistry 111, 41-55.

43. Moritz, L., Liang, C., Wagai, R., Kitayama, K., Balser, T., 2009. Vertical distribution and pools of microbial residues in tropical forest soils formed from distinct parent materials. Biogeochemistry 92, 83-94.

44. NWS, 2013. National Weather Service: Wisconsin 30 year average temperature and precipitation 1981-2010.

45. Oksanen, J., 2010. Multivariate Analysis of Ecological Communities in R: vegan tutorial, pp. 1-43.

46. Parsons, J.W., 1981. Chemistry and distribution of amino sugars in soils and soil organisms, In: Paul, E.A., J.N. Ladd (Ed.), Soil Biochemistry. Marcel Dekker, New York.

47. Peres-Neto, P.R., Legendre, P., Dray, S., Borcard, D., 2006. Variation partitioning of species data matrices: estimation and comparison of fractions. Ecology 87, 2614-2625.

48. Pinheiro, J., Bates, D., DebRoy, S., Sarkar, D., 2009. nlme: Linear and Nonlinear Mixed Effects Models. R package version 3, 1-96.

49. Post, W.M., Kwon, K.C., 2000. Soil carbon sequestration and land-use change: processes and potential. Global Change Biology 6, 317-327.

50. Powlson, D.S., Prookes, P.C., Christensen, B.T., 1987. Measurement of soil microbial biomass provides an early indication of changes in total soil organic matter due to straw incorporation. Soil Biology and Biochemistry 19, 159-164.

51. Ratledge, C., Wilkinson, S.G., 1988. Microbial lipids. Acdemic Press, London.

52. Rustad, L.E., Huntington, T.G., Boone, R.D., 2000. Controls on soil respiration: Implications for climate change. Biogeochemistry 48, 1-6.

53. Sanford, G., 2014. Perennial Grasslands Are Essential for Long Term SOC Storage in the Mollisols of the North Central USA, In: Hartemink, A.E., McSweeney, K. (Eds.), Soil Carbon. Springer International Publishing, pp. 281-288.

54. Sanford, G.R., Oates, L.G., Jasrotia, P., Thelen, K.D., Robertson, G.P., Jackson, R.D., 2016. Comparative productivity of alternative cellulosic bioenergy cropping systems in the North Central USA. Agriculture, Ecosystems \& Environment 216, 344-355.

55. Schimel, D.S., 1995. Terrestrial ecosystems and the carbon cycle. Global Change Biology 1, 77-91.

56. Schimel, J., Schaeffer, S.M., 2012. Microbial control over carbon cycling in soil. Frontiers in Microbiology 3.

57. Simpson, A., J,, Simpson, M.J., Smith, E., Kelleher, B.P., 2007. Microbially derived inputs to soil organic matter: are current estimates too low? Environ. Sci. Technol. 41, 8070-8076.

58. Soil Survey Staff, 1999. Soil Taxonomy - A basic system of soil classification for making and interpreting soil surveys, 2nd ed. Natural Resources Conservation Service and USDA, Washington DC, USA.

59. Sradnick, A., Oltmanns, M., Raupp, J., Joergensen, R.G., 2014. Microbial residue indices down the soil profile after long-term addition of farmyard manure and mineral fertilizer to a sandy soil. Geoderma 226-227, 79-84. 
60. Steinbeiss, S., BeßLer, H., Engels, C., Temperton, V.M., Buchmann, N., Roscher, C., Kreutziger, Y., Baade, J., Habekost, M., Gleixner, G., 2008. Plant diversity positively affects short-term soil carbon storage in experimental grasslands. Global Change Biology 14, 2937-2949.

61. Stephan, A., Meyer, A.H., Schmid, B., 2000. Plant diversity affects culturable soil bacteria in experimental grassland communities. Journal of Ecology 88, 988-998.

62. Thoms, C., Gattinger, A., Jacob, M., Thomas, F.M., Gleixner, G., 2010. Direct and indirect effects of tree diversity drive soil microbial diversity in temperate deciduous forest. Soil Biology and Biochemistry 42, 1558-1565.

63. Tilman, D., Reich, P.B., Knops, J., Wedin, D., Mielke, T., Lehman, C., 2001. Diversity and productivity in a long-term grassland experiment. Science 294, 843-845.

64. Treseder, K.K., Turner, K.M., Mack, M.C., 2007. Mycorrhizal responses to nitrogen fertilization in boreal ecosystems: potential consequences for soil carbon storage. Global Change Biology 13, 78-88.

65. Vestal, J.R., White, D.C., 1989. Lipid analysis in microbial ecology: quantitative approaches to the study of microbial community. BioScience 39, 535-541.

66. Wardle, D.A., Bardgett, R.D., Klironomos, J.N., Setälä, H., van der Putten, W.H., Wall, D.H., 2004. Ecological linkages between aboveground and belowground biota. Science 304, 1629-1633.

67. Wardle, D.A., Yeates, G.W., Williamson, W., Bonner, K.I., 2003. The response of a three trophic level soil food web to the identity and diversity of plant species and functional groups. Oikos 102, 45-56.

68. Zelles, L., 1999. Fatty acid patterns of phospholipids and lipopolysaccharides in the characterisation of microbial communities in soil: a review. Biology and Fertility of Soils 29, 111-129.

69. Zhang, X., Amelung, W., 1996. Gas chromatographic determination of muramic acid, glucosamine, mannosamine, and galactosamine in soils. Soil Biology and Biochemistry 28, 1201-1206.

70.Zogg, G.P., Zak, D.R., Ringelberg, D.B., White, D.C., MacDonald, N.W., Pregitzer, K.S., 1997. Compositional and functional shifts in microbial communities due to soil warming. Soil Sci Soc Am J 61, $475-481$. 
1 Table 1. Native species and functional guilds seeded in low diversity $(n=6)$ and high diversity

$2 \quad(\mathrm{n}=25)$ prairie sites in 1999

\begin{tabular}{|c|c|c|c|c|}
\hline $\begin{array}{l}\text { Functional } \\
\text { guild }\end{array}$ & Common name & Botanical name & $\begin{array}{c}\text { Low } \\
\text { diversity }\end{array}$ & $\begin{array}{c}\text { High } \\
\text { diversity }\end{array}$ \\
\hline woody shrub & pasture rose & Rosa carolina & & $\mathrm{X}$ \\
\hline $\mathrm{C} 4$ grass & big bluestem & Andropogon gerardii & $\mathrm{X}$ & $\mathrm{X}$ \\
\hline $\mathrm{C} 3$ grass & Canada wild rye & Elymus canadensis & $\mathrm{X}$ & $\mathrm{X}$ \\
\hline $\mathrm{C} 4$ grass & indiangrass & Sorgastrum nutans & & $\mathrm{X}$ \\
\hline legume & Canada milkvetch & Astragalus canadensis & & $\mathrm{X}$ \\
\hline legume & white wild indigo & Baptisia leucantha & & $\mathrm{X}$ \\
\hline legume & showy tick trefoil & Desmodium canadense & $\mathrm{X}$ & $\mathrm{X}$ \\
\hline legume & round-headed bush clover & Lespedeza capitata & $\mathrm{X}$ & $\mathrm{X}$ \\
\hline forb & wild onion & Allium cernuum & & $\mathrm{X}$ \\
\hline forb & butterfly milkweed & Asclepias tuberose & & $\mathrm{X}$ \\
\hline forb & New England aster & Aster novae-angliae & & $\mathrm{X}$ \\
\hline forb & prairie tickseed & Coreopsis palmata & & $\mathrm{X}$ \\
\hline forb & rattlesnake master & Eryngium yuccifolium & & $\mathrm{X}$ \\
\hline forb & northern bedstraw & Galium boreale & & $\mathrm{X}$ \\
\hline forb & prairie smoke & Geum triflorum & & $\mathrm{X}$ \\
\hline forb & sawtooth sunflower & Helianthus grosseserratus & & $\mathrm{X}$ \\
\hline forb & showy sunflower & Helianthus pauciflorous & & $\mathrm{X}$ \\
\hline forb & wild bergamot & Monarda fistulosa & & $\mathrm{X}$ \\
\hline forb & prairie cinquefoil & Potentilla arguta & & $\mathrm{X}$ \\
\hline forb & yellow coneflower & Ratibida pinnata & $\mathrm{X}$ & $\mathrm{X}$ \\
\hline forb & black-eyed susan & Rudbeckia hirta & $\mathrm{X}$ & $\mathrm{X}$ \\
\hline forb & rosinweed & Silphium integrifolium & & $\mathrm{X}$ \\
\hline forb & stiff goldenrod & Solidago rigida & & $\mathrm{X}$ \\
\hline forb & spiderwort & Tradescantia ohioensis & & $\mathrm{X}$ \\
\hline forb & prairie violet & Viola pedatifida & & $\mathrm{X}$ \\
\hline
\end{tabular}


5 Table 2. Effects (F-value) of plant diversity, soil depth and their interaction on soil

6 physicochemical properties according to general linear mixed model (GLMM) results.

\begin{tabular}{|c|c|c|c|}
\hline Variable & Diversity & Depth & Diversity $*$ Depth \\
\hline Total C (\%) & 0.27 &  & 0.16 \\
\hline Total N (\%) & 0.11 & $76.21^{\dot{*} \pi \dot{x}}$ & 0.25 \\
\hline $\mathrm{OM}(\%)$ & 0.07 & 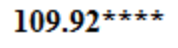 & 2.55 \\
\hline $\mathrm{P}(\mathrm{ppm})$ & 2.09 & $5.61^{*}$ & 1.78 \\
\hline $\mathrm{K}$ (ppm) & 0.51 & 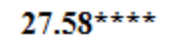 & 0.11 \\
\hline $\mathrm{Ca}(\mathrm{ppm})$ & 0.55 & 0.70 & 3.48 \\
\hline $\mathrm{Mg}(\mathrm{ppm})$ & 0.02 & $8.07^{* *}$ & 0.24 \\
\hline $\mathrm{CEC}$ & 0.17 & 1.09 & 0.19 \\
\hline $\mathrm{pH}$ value & 0.00 & 1.67 & 0.07 \\
\hline Clay (\%) & 0.33 & $4.08^{*}$ & 0.42 \\
\hline $\mathrm{C} / \mathrm{N}$ ratio & 0.54 & 2.41 & 0.90 \\
\hline Bulk density & 0.12 & $5.48^{*}$ & 0.13 \\
\hline
\end{tabular}

8 Bold numbers indicate significant effects at $* \mathrm{P}<0.05, * * \mathrm{P}<0.01, * * * \mathrm{P}<0.001$, $* * * * \mathrm{P}<$ $9 \quad 0.0001$, respectively. 
Figure $1 \mathrm{~A}$

$-0.8$

$-0.6$

$-0.4$

$-0.2$

0.0

0.2

0.4

0.6

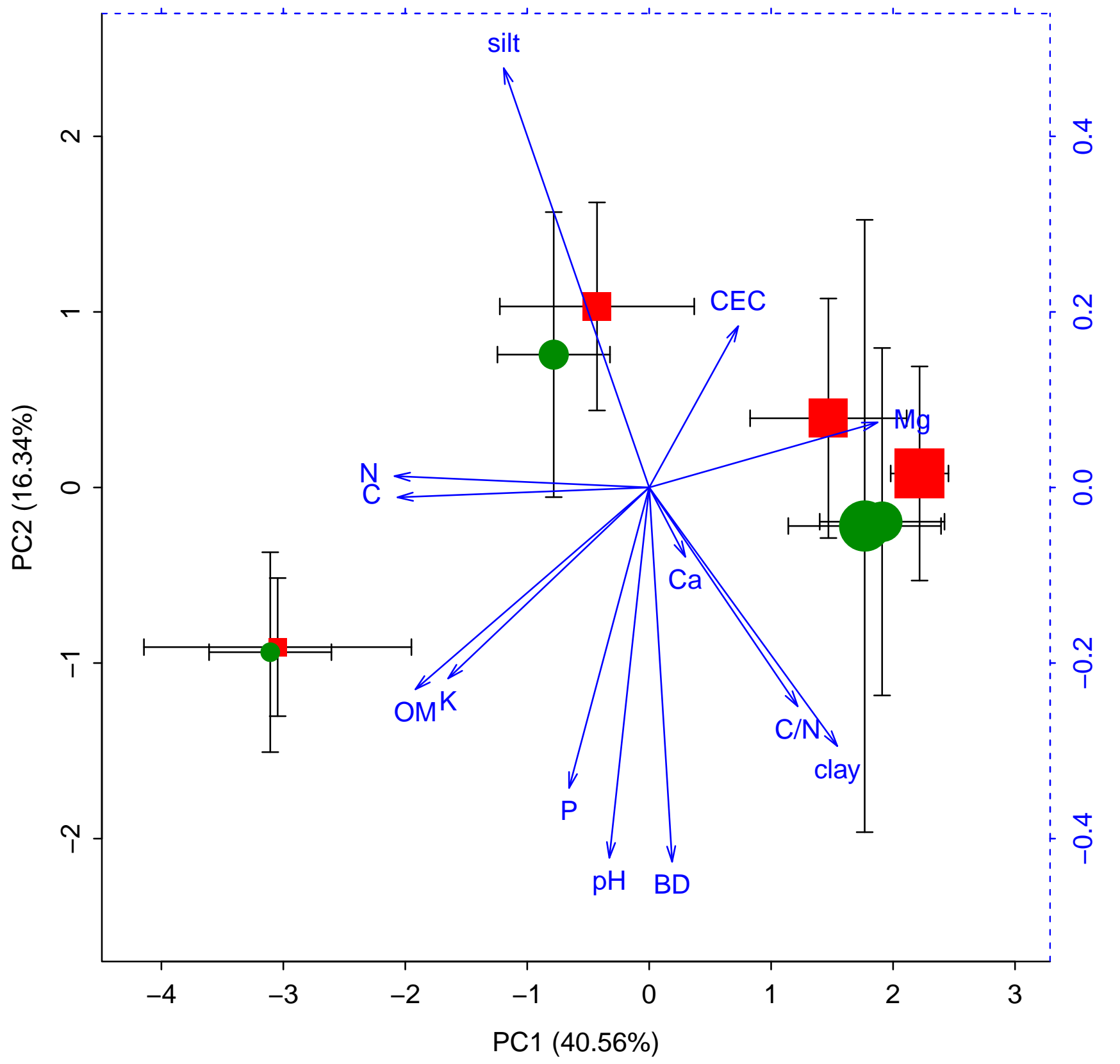




Total carbon amount $(\mathrm{g} / \mathrm{kg})$
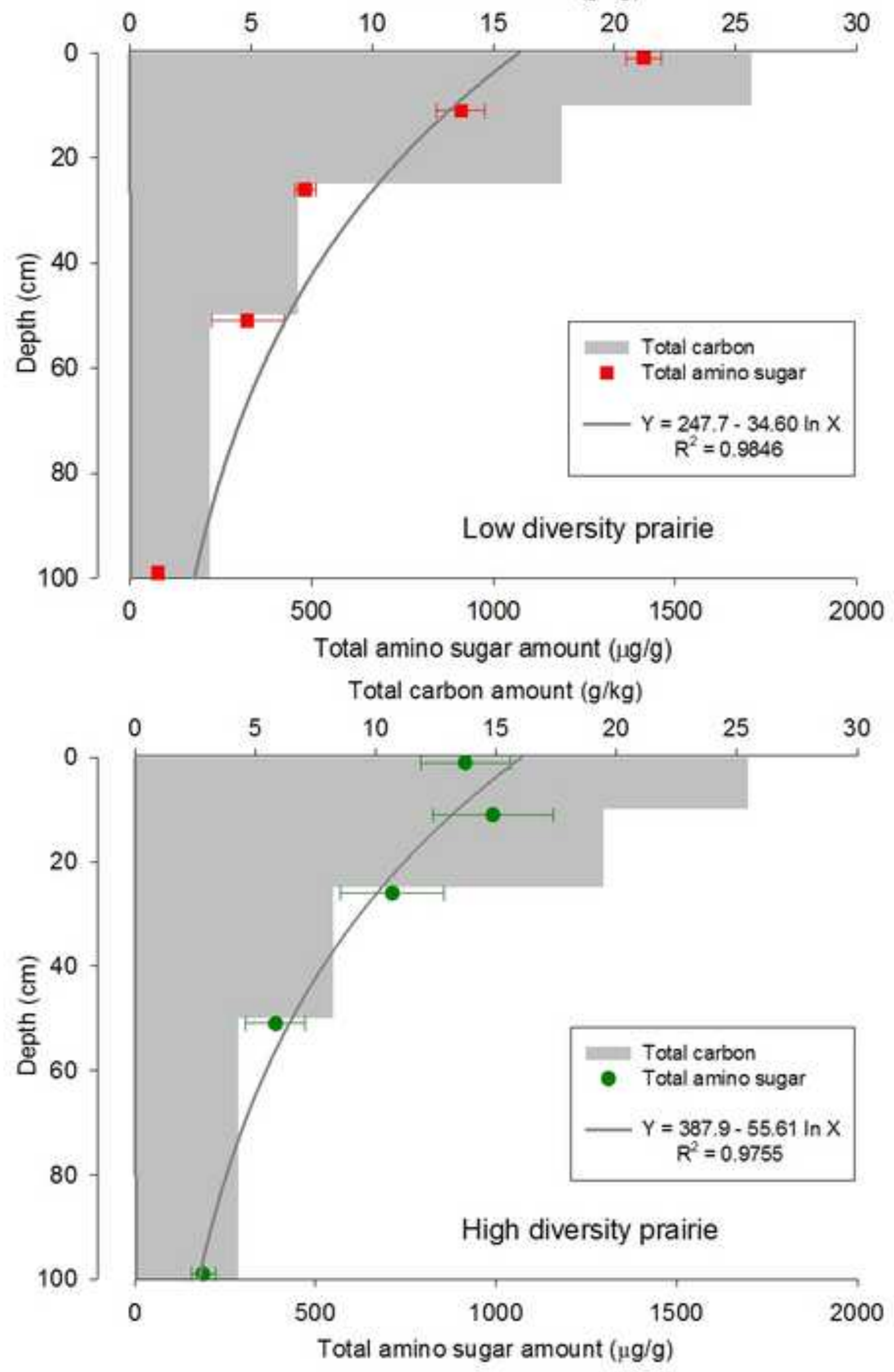
GluN/MurA ratio

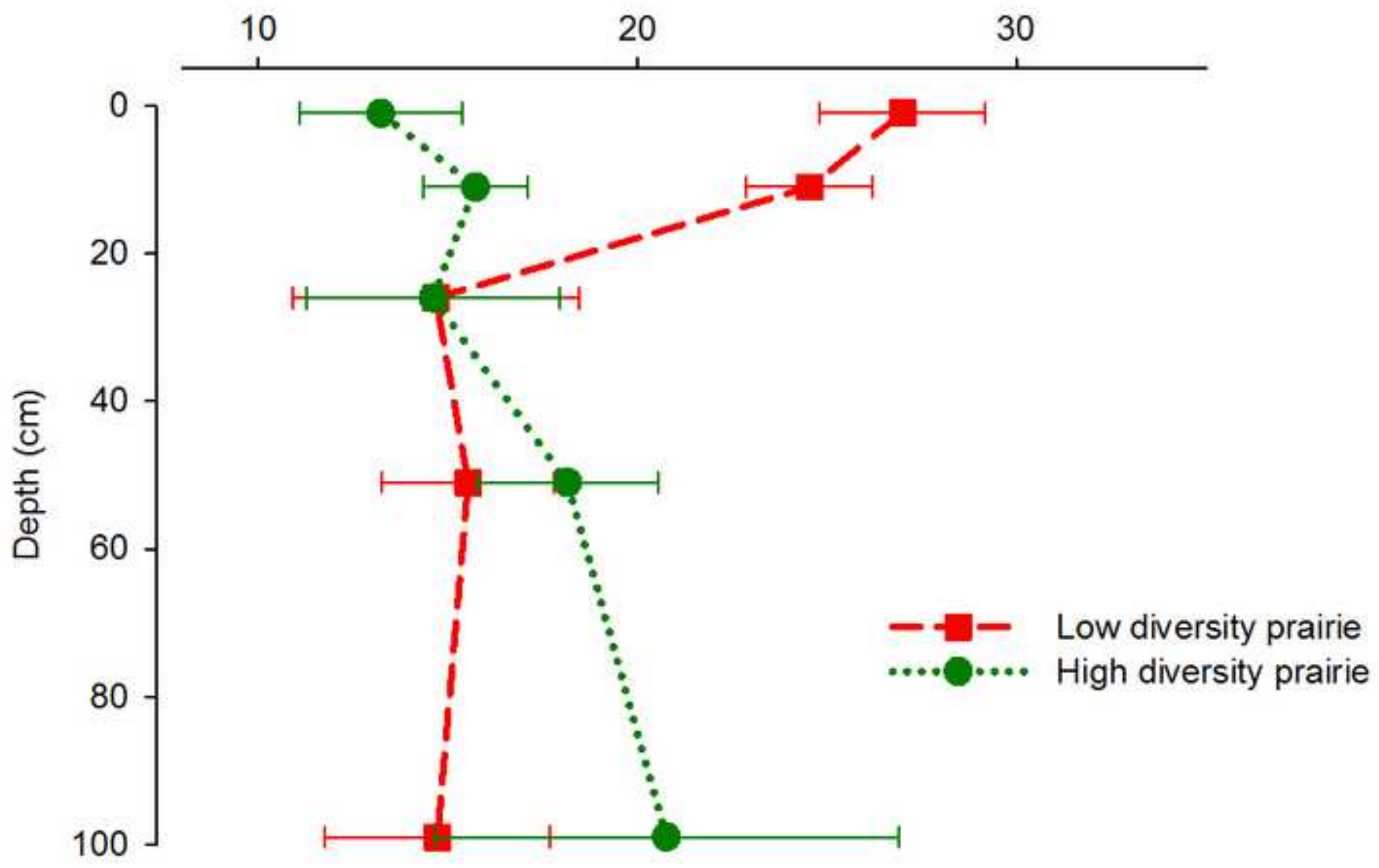




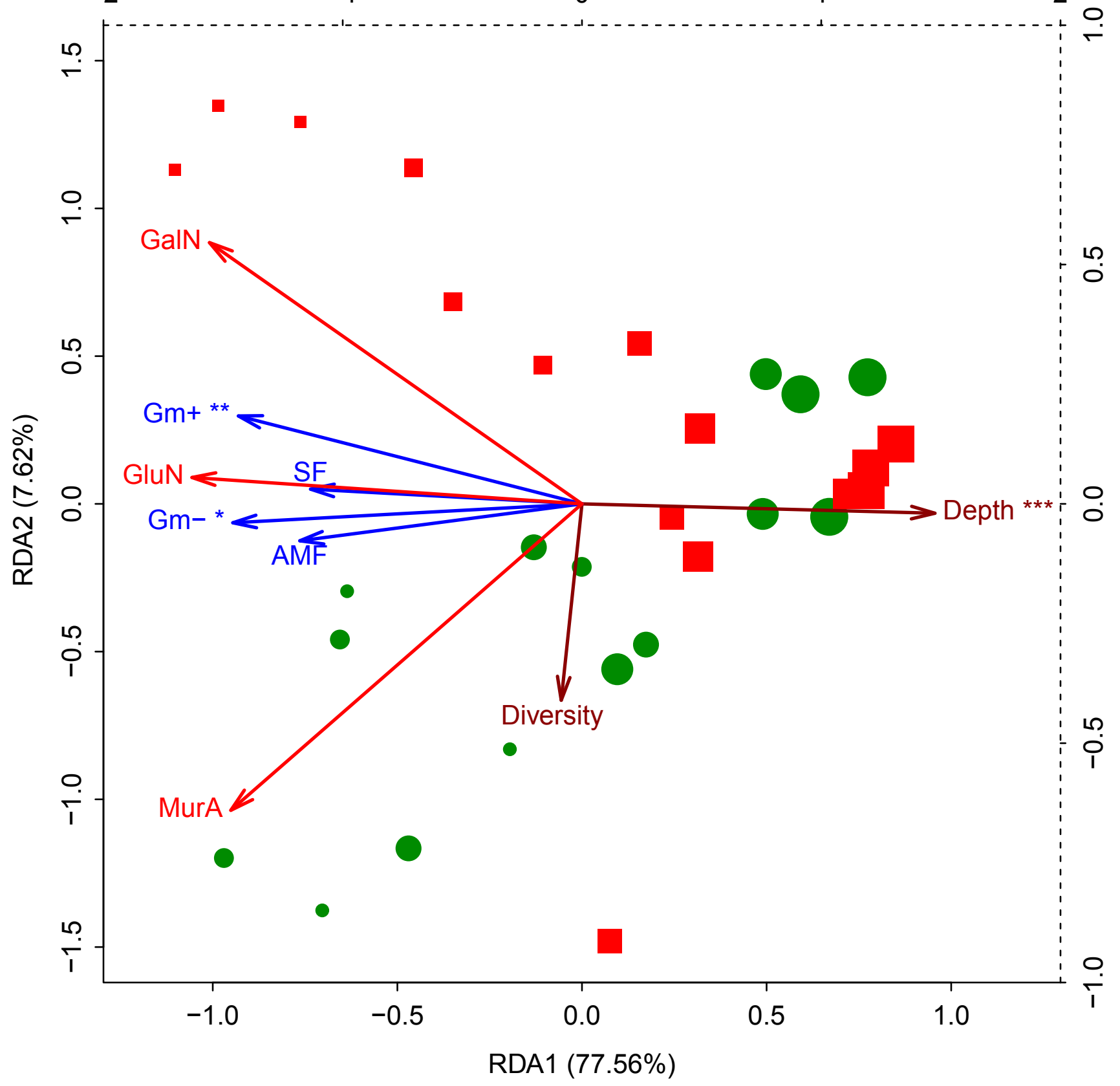



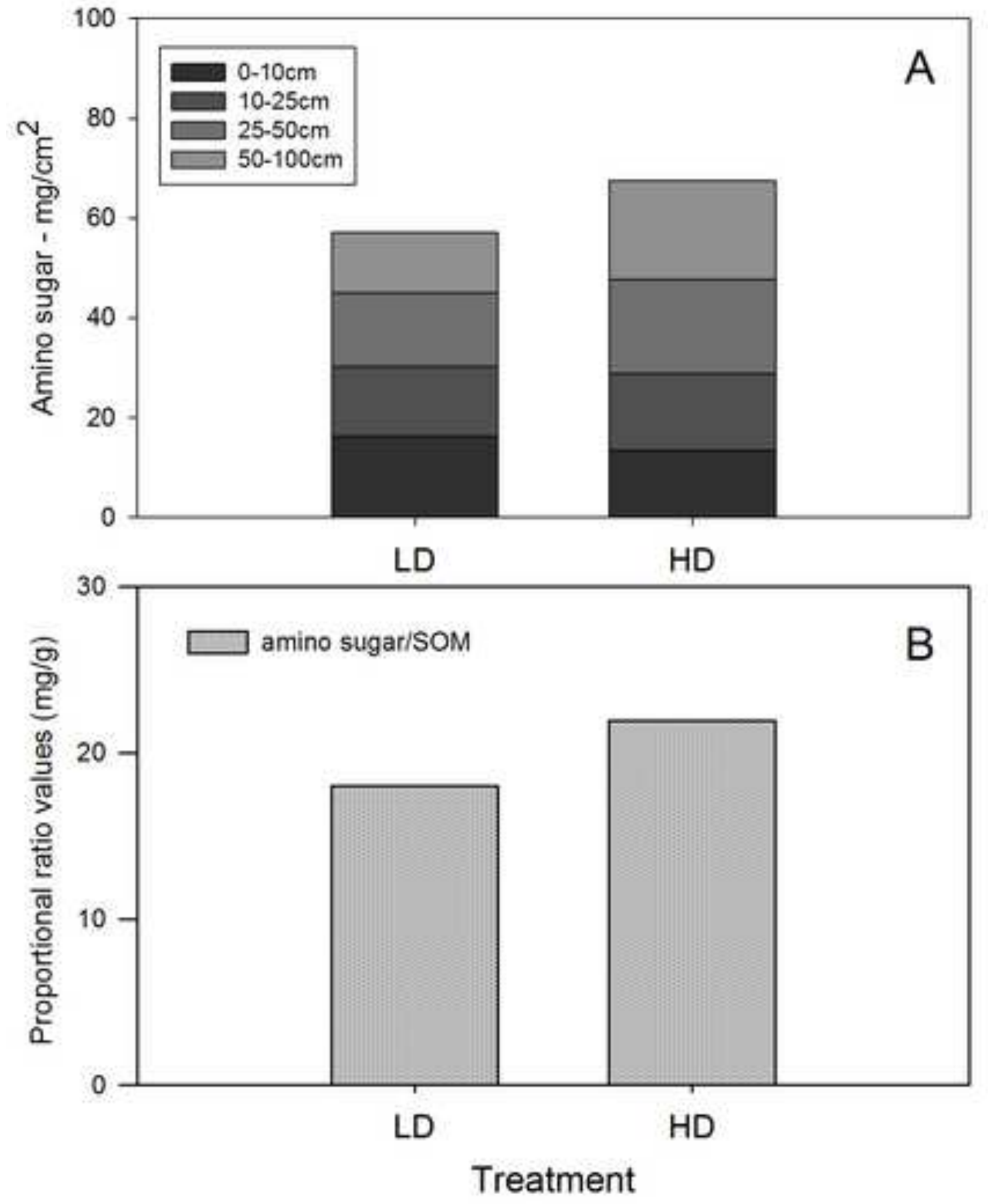